\title{
Formulasi Es Krim Sari Kurma
}

\author{
Agustin Cesia ${ }^{1}$ dan Judiono ${ }^{1}$ \\ 'Jurusan Gizi Politeknik Kesehatan Kemenkes Bandung \\ Email : cesiaagustin@gmail.com
}

\begin{abstract}
ABSTRAK : Demam Berdarah Dengue merupakan salah satu masalah kesehatan di Indonesia. Penderita DBD biasanya akan terjadi penurunan trombosit, dan mengalami penurunannya respon daya tahan tubuh. Salah satu zat gizi yang dapat meningkatkan trombopoietin adalah omega 6 atau asam linoleat, adalah sari kurma. Penelitian ini bertujuan untuk mengetahui gambaran tingkat kesukaan terhadap es krim sari kurma. Desain penelitian adalah studi eksperimental, dengan sampel 30 orang panelis yang mengisi lembar formulir uji hedonik. Data yang dikumpulkan meliputi warna, rasa, aroma dan tekstur. Es krim sari kurma yang paling banyak disukai dari segi warna yaitu formula 366 , rasa yang paling disukai formula 455, aroma yang paling disukai yaitu formula 904 dan tekstur formula 455. Jadi, produk yang dipilih paling unggul adalah formula 455, karena disukai dari segi rasa dan tekstur. Berdasarkan hasil penelitian, produk es krim sari kurma yang harus diperbaiki dari segi warna dan aroma pada formulasi 366 dan 904 , perlu dilakukan penelitian lebih lanjut pada pasien DBD yang diberikan es krim sari kurma.
\end{abstract}

Kata Kunci : Es krim, kurma, sari kurma, es krim sari kurma, DBD

ABSTRACT : Dengue is one of health problems in Indonesia. Usually, dengue sufferers will decrease the body stamina responses. One of the nutrient substances which can increase thrombopoitein is omega 6 or linoleic acid in dates extract. This research is using experimental stufy, with samples as many as 30 panellist who filled hedonic test worksheet. The collected data are colour, taste, aroma and texture. Ice cream with dates extract which is liked most from colour side is formula 366, from taste side is formula 455 , from aroma side is formula 904, and from texture side is formula 455 . So, the product that is chosen most is formula 455 , because it is liked from taste and texture side. According to the result of the research, ice cream with dates extract product shoul be repaired both in colour and aroma side in formulation 366 and 904, and need to conduct an advance research to dengue sufferers who are given ice cream with dates extract.

Keyword : Ice cream, dates, dates extract, ice cream with dates extract, dengue 


\section{PENDAHULUAN}

Demam Berdarah Dengue menjadi salah satu permasalahan kesehatan di Indonesia. Pada penderita DBD akan terjadi penurunan trombosit, trombosit berfungsi juga dalam mendorong respon daya tahan tubuh, maka dari itu trombosit juga berfungsi dalam memperkuat daya tahan tubuh. Maka dari itu perlunya peningkatan energi maupun trombosit pada pasien, untuk meningkatkan kadar trombosit terdapat cara alternatif salah satunya adalah mengkonsumsi buah kurma atau sari kurma. Jus kurma dan diit rumah sakit merupakan makanan yang mampu meningkatkan status gizi pasien yang mengalami kekurangan kadar trombosit darah. ${ }^{1}$

Sari kurma berasal dari kurma yang diperas atau diambil sarinya, sehingga berbentuk cair. Sari kurma dan kurma memiliki manfaat yang sama hanya proses pengolahannya yang berbeda. Kedua zat ini memiliki manfaat bagi kesehatan. Menurut penelitian terdahulu menunjukkan presentase peningkatan jumlah trombosit dengan memberikan sari kurma dengan dosis $30 \mathrm{ml}$ per hari walaupun tidak terlihat nyata. ${ }^{2}$

Pada pasien Demam Berdarah Dengue biasanya dipercaya dengan meminum jus jambu sebagai peningkat kadar trombosit, tapi sebenarnya jus jambu hanya mengatasi kehilangan cairan akibat tubuh yang lemah karena turunnya kadar trombosit, sedangkan pemberian daun jambu biji lebih efektif meningkatkan kadar trombosit dibanding dengan buah jambunya. ${ }^{3}$

Pemberian jus kurma pada pasien demam berdarah relatif efektif dalam menaikkan kadar trombosit darah dengan kelompok kontrol $(p=0,039)$, dan juga adanya kandungan kurma yang kaya akan asam folat, vitamin B12, Zn, $\mathrm{Fe}$, zat gula serta enzim yang mudah di metabolisme oleh tubuh sehingga lebih cepat dalam meningkatkan kadar trombosit darah. ${ }^{4}$

Kemajuan pengetahuan dan teknologi yang sedang berkembang saat ini memungkinkan banyaknya aplikasi atau alternatif dalam pengolahan produk pangan yang mudah dan bermanfaat dalam kandungan gizi nya. Salah satunya adalah pembuatan produk yang es krim yang berasal dari bahan dasar berupa sari buah maupun sayur.

\section{METODE}

Penelitian ini merupakan penelitian eksperimental dengan rancangan acak lengkap (RAL) satu faktorial uji organoleptik. Variabel independen yaitu Es Krim Sari Kurma dengan formulasi sari kurma dan gula pasir 50\%:50\%, 70\%:30\%, 30\%:70\% berpengaruh terhadap variabel dependen yaitu uji hedonik yang meliputi sangat tidak suka , tidak suka, agak tidak suka, netral, agak suka, sangat suka, dan amat sangat suka.

Tempat penelitian pendahuluan dan utama dilakukan di Laboratorium Teknologi Pangan. Penelitian dilakukan dua tahap yaitu penelitian pendahuluan dan utama. Waktu penelitian pendahuluan dilakukan sejak bulan November-Desember 2016, penelitian utama dilakukan pada bulan JanuariFebuari 2017 pukul 13.00, selanjutnya setelah melakukan uji coba penelitian utama dilakukan analisa data.

Hasil data dari setiap panelis akan digabungkan dan ditabulasikan sehingga bisa dilihat apakah ada perbedaan uji kesukaan dari ketiga formula es krim dari kurma yang berbeda. Semua data yang telah dikumpulkan akan diolah dan di edit dengan software. Analisis data dilakukan secara univariat, dengan menggunakan software. Analisis univariat dilakukan untuk menyajikan data dalam bentuk deskriptif. Data yang 
akan dianalisis adalah hasil dari uji hedonik. Hasil data yang telah diolah dibuat menjadi grafik dengan menggunakan excel dan hasil grafik diberi narasi setiap kategori penilaian uji hedonik.

\section{HASIL}

\section{Hasil pengujian organoleptik}

\section{Penilaian Es Krim Sari Kurma Terhadap Warna}

Hasil uji hedonik es krim sari kurma terhadap warna disajikan sebagai berikut.

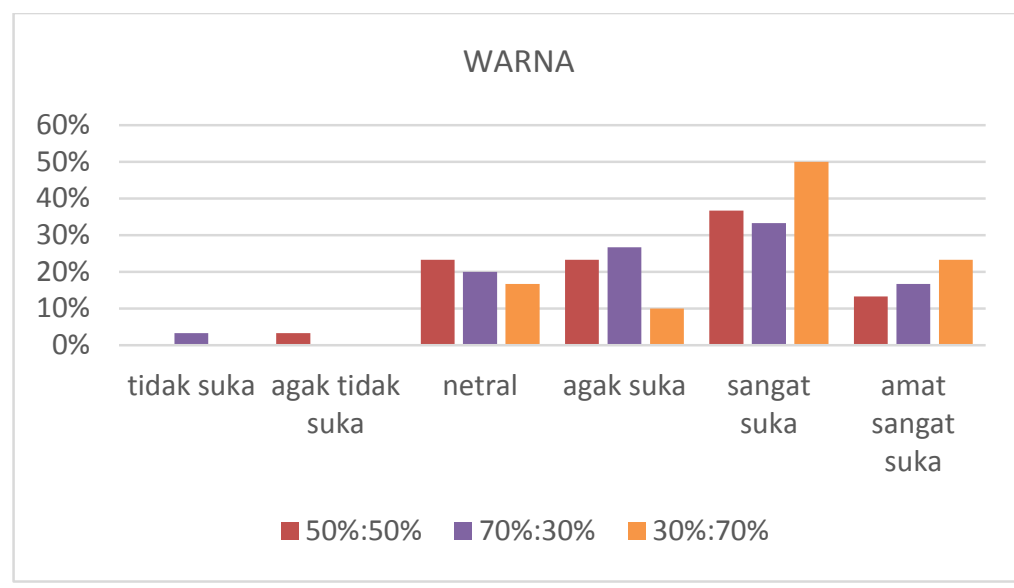

\section{GAMBAR 1}

\section{SEBARAN PENILAIAN PANELIS TERHADAP WARNA ES KRIM}

Berdasarkan gambar 1 dapat dilihat bahwa penilaian panelis terhadap warna es krim Sari Kurma dengan formulasi sari kurma dan gula pasir 50\%:50\% yaitu 36,7\% sangat suka, $13,3 \%$ amat sangat suka, agak suka $23,3 \%$. Formulasi sari kurma dan gula pasir 70\%:30\% yaitu 33,3\% sangat suka, 16,7\% amat sangat suka, dan agak suka 20 . Formulasi sari kurma dan gula pasir $30 \%: 70 \%$ yaitu $50 \%$ sangat suka, $23,3 \%$ amat sangat suka, dan 10\% agak suka. Dari hasil tersebut bahwa panelis lebih menyukai warna es krim sari kurma dengan formulasi sari kurma $30 \%$ dan gula pasir $70 \%$.

\section{Penilaian Es Krim Sari Kurma Terhada Rasa}

Hasil uji hedonik es krim sari kurma terhadap rasa disajikan sebagai berikut. 


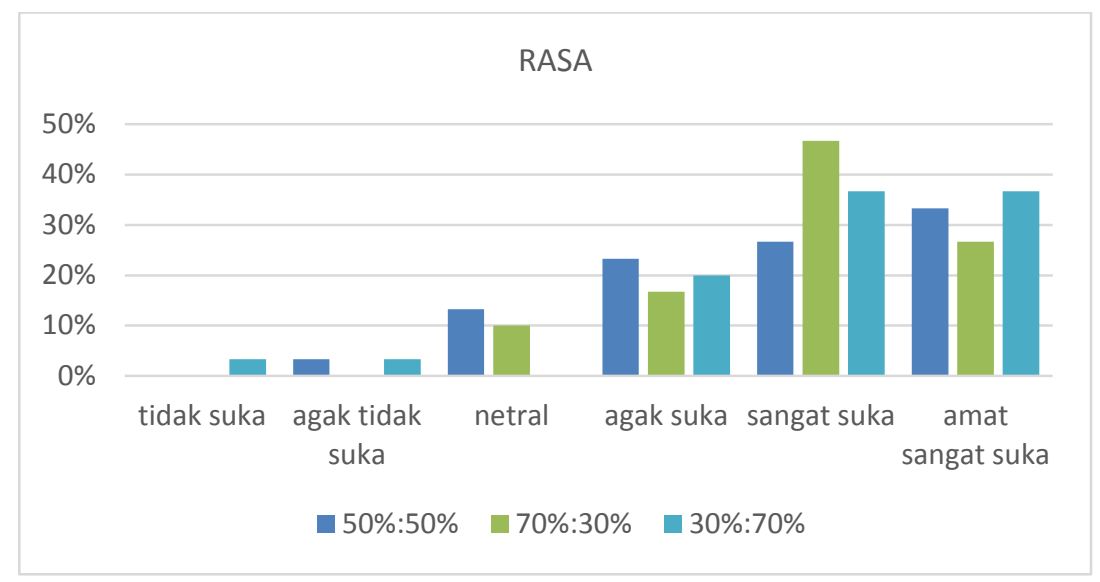

\section{GAMBAR 2}

\section{SEBARAN PENILAIAN PANELIS TERHADAP RASA ES KRIM}

Berdasarkan gambar 2 dapat dilihat bahwa penilaian panelis terhadap rasa es krim Sari Kurma dengan formulasi sari kurma dan gula pasir 50\%:50\% yaitu $26,7 \%$ sangat suka, $33,3 \%$ amat sangat suka, agak suka $23,3 \%$, dan agak tidak suka $3,3 \%$. Formulasi sari kurma dan gula pasir $70 \%: 30 \%$ yaitu $26,7 \%$ sangat suka, $46,7 \%$ amat sangat suka, dan agak suka $16,7 \%$. Formulasi sari kurma dan gula pasir $30 \%: 70 \%$ yaitu $36,7 \%$ sangat suka, 36,7\% amat sangat suka, $20 \%$ agak suka, agak tidak suka $3,3 \%$, dan tidak suka 3,3\%. Dari hasil tersebut bahwa panelis lebih menyukai rasa es krim sari kurma dengan formulasi sari kurma $70 \%$ dan gula pasir $30 \%$.

\section{Penilaian Es Krim Sari Kurma Terhada Aroma}

Hasil uji hedonik es krim sari kurma terhadap aroma disajikan sebagai berikut.

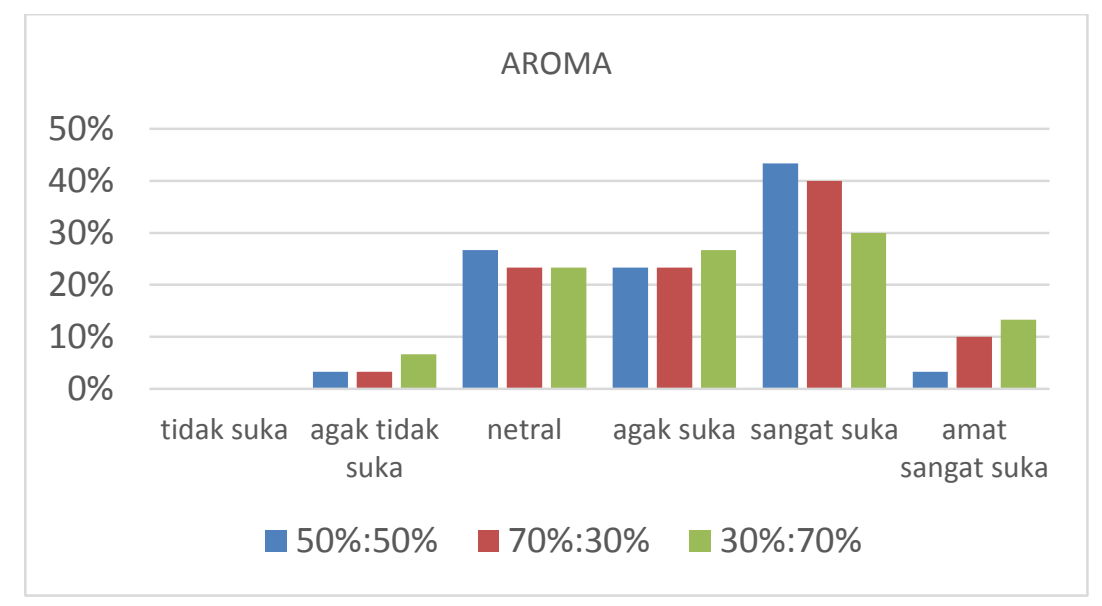

\section{GAMBAR 3}

\section{SEBARAN PENILAIAN PANELIS TERHADAP AROMA ES KRIM}

Berdasarkan gambar 3 dapat dilihat bahwa penilaian panelis terhadap aroma es krim Sari Kurma dengan formulasi sari kurma dan gula pasir 50\%:50\% yaitu $43,3 \%$ sangat suka, 3,3\% amat sangat suka, agak suka 23,3\%, dan agak tidak suka 3,3\%. Formulasi sari kurma dan gula pasir 70\%:30\% yaitu $40 \%$ sangat suka, 10\% amat sangat 
suka, dan agak suka 23,3\%. Formulasi sari kurma dan gula pasir 30\%:70\% yaitu $30 \%$ sangat suka, $13,3 \%$ amat sangat suka, $26,7 \%$ agak suka, agak tidak suka $6,7 \%$. Dari hasil tersebut bahwa panelis lebih menyukai aroma es krim sari kurma dengan formulasi sari kurma $50 \%$ dan gula pasir $50 \%$.

\section{Penilaian Es Krim Sari Kurma Terhadap Tekstur}

Hasil uji hedonik es krim sari kurma terhadap tekstur disajikan sebagai berikut.

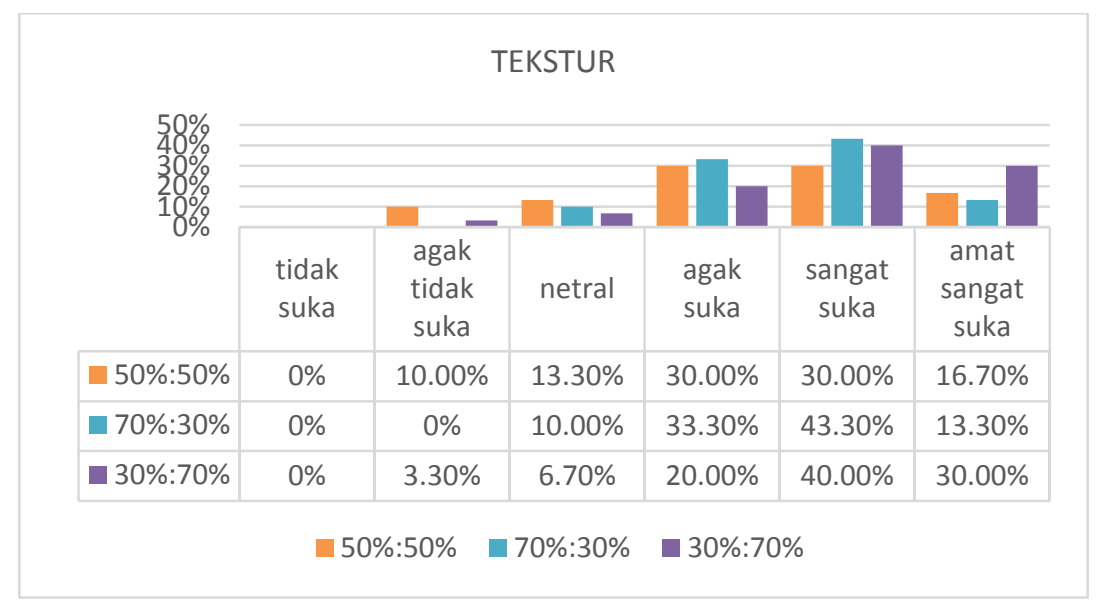

\section{GAMBAR 4}

\section{SEBARAN PENILAIAN PANELIS TERHADAP TEKSTUR ES}

Berdasarkan gambar 4 dapat dilihat bahwa penilaian panelis terhadap aroma es krim Sari Kurma dengan formulasi sari kurma dan gula pasir $50 \%: 50 \%$ yaitu $30 \%$ sangat suka, $16,7 \%$ amat sangat suka, agak suka $30 \%$, dan agak tidak suka $10 \%$. Formulasi sari kurma dan gula pasir 70\%:30\% yaitu $43 \%$ sangat suka, $13,3 \%$ amat sangat suka, dan agak suka $33,3 \%$. Formulasi sari kurma dan gula pasir 30\%:70\% yaitu $40 \%$ sangat suka, 30\% amat sangat suka, $20 \%$ agak suka, agak tidak suka 3,3\%. Dari hasil tersebut bahwa panelis lebih menyukai tekstur es krim sari kurma dengan formulasi sari kurma $70 \%$ dan gula pasir $30 \%$.

\section{Analisi Nilai Gizi}

Analisis kandungan gizi dapat dilihat pada tabel berikut.

Tabel 1

Nilai Gizi Es Krim Sari Kurma

\begin{tabular}{|c|c|c|c|c|c|c|c|c|c|c|c|c|}
\hline \multirow[b]{2}{*}{$\begin{array}{l}\text { Bahan } \\
\text { Makanan }\end{array}$} & \multicolumn{4}{|c|}{904} & \multicolumn{4}{|c|}{455} & \multicolumn{4}{|c|}{366} \\
\hline & $\begin{array}{c}\mathrm{E} \\
\text { (kkal) }\end{array}$ & $\begin{array}{l}P \\
(g)\end{array}$ & $\begin{array}{l}\mathrm{L} \\
(\mathrm{g})\end{array}$ & $\begin{array}{l}\mathrm{KH} \\
(\mathrm{g})\end{array}$ & $\begin{array}{c}\mathrm{E} \\
(\mathrm{kkal})\end{array}$ & $\begin{array}{l}P \\
(g)\end{array}$ & $\begin{array}{c}\mathrm{L} \\
(\mathrm{g})\end{array}$ & $\begin{array}{l}\mathrm{KH} \\
(\mathrm{g})\end{array}$ & $\begin{array}{c}\mathrm{E} \\
\text { (kkal) }\end{array}$ & $\begin{array}{l}P \\
(g)\end{array}$ & $\begin{array}{l}\mathrm{L} \\
(\mathrm{g})\end{array}$ & $\begin{array}{l}\mathrm{KH} \\
(\mathrm{g})\end{array}$ \\
\hline $\begin{array}{l}\text { Susu } \\
\text { skim }\end{array}$ & 2208 & 241 & 12,6 & 309 & 2208 & 214 & 12,6 & 309 & 2209 & 214 & 12,6 & 309 \\
\hline $\begin{array}{l}\text { Sari } \\
\text { kurma }\end{array}$ & 618 & 26,93 & 1,01 & 165 & 1732 & 75,4 & 75,4 & 463 & 742 & 32,3 & 1,21 & 197 \\
\hline $\begin{array}{l}\text { Krim } \\
\text { segar }\end{array}$ & 102 & 0,6 & 1,11 & 0,84 & 102 & 0,6 & 0,6 & 0,84 & 102 & 0,6 & 11,1 & 0,84 \\
\hline $\begin{array}{l}\text { Gula } \\
\text { pasir }\end{array}$ & 812 & 0 & 0 & 209 & 812 & 0 & 0 & 209 & 812 & 0 & 0 & 209 \\
\hline total & 3740 & 241,5 & 14,72 & 683,84 & 4854 & 290 & 290 & 981,84 & 3864 & 246,9 & 24,91 & 715,84 \\
\hline $\begin{array}{l}\text { Total per } \\
\text { cup }\end{array}$ & 124,67 & 8,05 & 0,49 & 22,79 & 161,8 & 9,67 & 9,67 & 32,74 & 128,8 & 8,23 & 0,83 & 23,86 \\
\hline
\end{tabular}


Berdasarkan tabel 1 dapat dilihat bahwa nilai gizi es krim sari kurma per cupnya dengan kode 904 adalah energi 124,7 kkal, protein 8,05 gram, lemak 0,49 gram, karbohidrat 22,79 gram. Nilai gizi es krim kurma kode 455 adalah energi 161,8 kkal, protein 9,67, lemak 9,67 dan karbohidratnya 32,7 sedangkan kode 366 energinya 128,8, proteinnya 8,23 gram, lemaknya 0,83 gram, dan karbohidratnya 23,86.

\section{PEMBAHASAN}

Berdasarkan hasil penilaian uji hedonik pada es krim sari kurma pada warna yaitu pada formulasi 50\%:50\% dihasilkan warna coklat muda, formulasi 70\%:30\% coklat muda tetapi warna lebih kecoklatan dibanding formulasi 50\%:50\% dan formulasi 30\%:70\% warna coklat seulas saja karena pada formula ini penambahan sari kurmanya paling sedikit yaitu hanya $270 \mathrm{ml}$. Jadi, kesimpulan dari ketiga formulasi es krim sari kurma ini yang paling disuka warnanya adalah pada formulasi 30\%:70\% karena warna tidak teralu pekat, warnanya cokelat muda dan lebih terang sehingga lebih menarik. Warna pada es krim ini dipengaruhi oleh penambahan kurma sehingga warna agak kecoklatan. Zat warna kurma ini berasal dari tanin sehingga berwarna kecoklatan.

Hasil penilaian uji hedonik pada rasa yang dinilai oleh 30 panelis yaitu formulasi 50\%:50\% banyak memilih kategori amat sangat suka, menurut panelis formulasi 50\%:50\% tidak terlalu manis rasanya karena pada formulasi 50\%:50\% penambahan sari kurma 450 $\mathrm{ml}$ dan gula pasir $210 \mathrm{gr}$, formulasi 70\%:30\% yang banyak dipilih yaitu kategori sangat suka sebesar $46,70 \%$, menurut panelis pada formula ini rasanya manis bersumber dari sari kurma dan rasa susu juga terasa hanya pada formula ini tidak ada rasa yang terlalu dominan, formulasi 30\%:70\% yang banyak dipiih oleh panelis yaitu kategori sangat suka dan amat sangat suka seimbang yaitu sebesar $36,70 \%$. Rasa manis es krim sari kurma bersumber pada kurma yang matang dan pati dalam buah kurma akan berubah menjadi glukosa dan fruktosa sehingga rasanya manis. ${ }^{5}$
Hasil pengamatan keseluruhan formulasi didapatkan yang paling disuka pada pengamatan rasa yaitu pada formulasi 70\%:30\% karena rasa yang tidak terlalu mendominasi antara susu dan sari kuma. Komponen bioaktif dari susu mengandung laktosa sehingga mempertahankan palatabilitas (rasa enak) es krim dan mempertahankan cita rasa. Sumber komponen bioaktif lainnya salah satunya adalah protein yaitu kasein yang merupakan sumber protein utama susu yang berjumlah sebesar $80 \%$ total protein susu. Terdapat juga komponen bioaktif dalam susu yang memiliki efek kesehatan yaitu kaseinfosfopeptida, peptida susu antihipertensi, laktoferin, glikoakropeptida, dan asam linoleat. ${ }^{6}$ Kurma mengandung gula sukrosa, fruktosa dan glukosa. Rasa manis pada es krim berasal dari kandungan gula dari sari kurma dan rasa gurih yang berasal dari krim segar.

Hasil uji hedonik pada aroma oleh 30 panelis didapatkan hasil yaitu formulasi 50\%:50\% yang paling banyak dipilih kategori sangat suka sebesar 43,30\% karena formulasi 50\%:50\% sedikit tercium aroma sari kurm dan susu, hanya dari kedua bahan tersebut tidak ada yang dominan, formulasi 70\%:30\% yang banyak dipilih pada kategori sangat suka sebesar $40 \%$ karena formulasi 70\%:30\% paling banyak penambahan sari kurmanya sebesar $630 \mathrm{ml}$, tetapi panelis lebih menyukai aroma pada formulasi 50\%:50\% karena aromanya yang tidak terlalu menyengat pada es krim sari kurma tetapi masih tercium sedikit, formulasi 30\%:70\% yang banyak dipilih pada kategori sangat suka sebesar 30\%, formulasi 30\%:70\% paling sedikit presentasenya dibanding penilaian 
formulasi $50 \%: 50 \%$ dan $70 \%: 30 \%$, karena pada formulasi 30\%:70\% ini penambahan sari kurmanya paling sedikit yaitu $270 \mathrm{ml}$. Formulasi yang paling disukai aromanya adalah pada formulasi 50\%:50\% karena aroma sari kurma dan susu seimbang, dibanding dengan formulasi 70\%:30\% yang penambahan sari kurmanya lebih banyak yaitu sebesar $630 \mathrm{ml}$ daripada formulasi $\quad 50 \%: 50 \%$ dengan penambahan sari kurma sebesar 450 $\mathrm{ml}$.

Hasil dari uji hedonik formulasi 50\%:50\%, 70\%:30\%, dan 30\%:70\% didapatkan kesimpulan dari ketiga formulasi es krim sari kurma ini yang paling disuka dari segi tekstur adalah pada formulasi 70\%:30\% dengan presentase $43,3 \%$ pada kategori sangat suka, dengan alasan secara keseluruhan menurut panelis tekstur sudah cukup lembut dan halus, tidak terlalu banyak remahan dari sari kurma dibandingkan formulasi lainnya. Pada es krim sari kurma, gula berperan dalam

\section{KESIMPULAN}

Berdasarkan penelitian yang telah dilakukan pada es krim sari kurma dengan menggunakan uji hedonik didapatkan hasil :

1. Formulasi $30 \%: 70 \%$ yang paling disukai dari segi warna

2. Formulasi $70 \%: 30 \%$ yang paling disukai dari segi rasa

3. Formulasi 50\%:50\% yang paling disukai dari segi aroma

4. Formuasi $70 \%: 30 \%$ yang paling disukai dari segi tekstur.

Jadi, kesimpulan dari ketiga formulasi ini yang paling unggul disukai oleh 30 panelis yaitu formulasi $70 \%: 30 \%$ karena dilihat dari segi warna dan tekstur yang paling disukai. Berdasarkan menentukan tekstur es krim. Penambahan gula pasir dapat menurunkan titik beku adonan sehingga tidak terlalu cepat meleleh saat diproses. Pengaturan titik beku berpengaruh pada tekstur menjadi lebih lembut. Tesktur pada es krim juga dipengaruhi oleh CMC. Penambahan CMC dapat membantu mengikat sejumlah air bebas sehingga tekstur es krim relatif lebih halus selain itu sedikit air bebas yang tersedia untuk membentuk kristal es memungkinkan dihasilkannya kristal es yang lebih kecil dalam es krim dan ukuran es kristal es sangat memberikan pengaruh pada tekstur es krim. ${ }^{7}$ Suhu simpan es krim juga mempengaruhi tekstur yang mudah meleleh atau tidak, pada ketiga formulasi es krim ini kendalanya adalah pada penyimpanan nya karena kulkas tidak terlalu dingin sehingga tekstur pada es krim agak mudah meleleh saat dikeluarkan pada suhu ruang. Dan penambahan sari kurma pada es krim menambah tekstur es krim menjadi ada remah - remah.

penelitian yang telah dilakukan dan dilihat dari keismpulan yang ada, produk es krim sari kurma dapat dijadikan sebagai pangan fungsional dan sari kurma alternatif makanan yang aman bagi penderita $\mathrm{DBD}$, sari kurma dapat meningkatkan kadar trombosit. Namun, belum ada penelitian yang menyebutkan adanya peningkatan kadar trombosit dengan mengkonsumsi es krim sari kurma, jadi perlu adanya penelitian lebih lanjut lagi. Produk yang paling unggul adalah formulasi $70 \%: 30 \%$ pada rasa dan tekstur, tetapi dari segi warna dan aroma masih perlu diperbaiki karena pada aroma dan tekstur yang disukai oleh 30 panelis yaitu pada formulasi 30\%:70\% dan 50\%:50\%. 


\section{DAFTAR PUSTAKA}

1. Duma N, Darmawansyah, Arsin A.A. Analisi Faktor Yang Berhubungan Dengan Kejadian Demam Berdarah Dengue Di Kecamatan Baruga Kota Kendari 2007. Analisis Occurrence of DHF, Vol.4 No. 2, September 2007:91-100.

2. Kusuma, M.A.N. 2009. Metabolisme Sari Kurma Pada Pasien Demam Berdarah Dengue: Studi Hematologis. (Online), http://repository.ipb.ac.id/handle/ , diakses pada tanggal 25 Juli 2019

3. Rabbaniya, Fairuz. 2015. Pengaruh Pemberian Ekstrak Daun Jambu Biji (Psidium guajava Linn) terhadap Peningkatan Trombosit pada Pasien Demam Berdarah Dengue. Dikutip pada tanggal 18 Desember 2016.
4. Giyatmo. 2013. Efektifitas Pemberian Jus Kurma Dalam Meningkatkan Trombosit Pada Paien Demam Berdarah Dengue Di RSU Bunda. Purwekerto: Jurnal Keperawatan Soedirman (The Journal of Nursing).Vol.8, No 1

5. Satuhu, S. 2010. Kurma, Kasiat dan Olahannya. Jakarta: Penebar Swadaya. Hal. 7-10.

6. Subroto, M. A. 2008. Real Food True Health. Agromedia Pustaka. Jakarta.

7. Maslikhah, Frida. 2015. Penambahan Karagenan Pada Es Krim. Jember: Universitas Negeri Jember. 